\title{
READJUSTING TRADE-OFFS AMONG CRITERIA IN INTERNAL RATINGS OF CREDIT-SCORING: AN EMPIRICAL ESSAY OF RISK ANALYSIS IN MORTGAGE LOANS
}

\author{
Fernando A. F. Ferreira ${ }^{1}$, Ronald W. Spahr ${ }^{2}$, Irina F. M. D. Gavancha ${ }^{3}$, \\ Amali Çipi ${ }^{4}$ \\ ${ }^{1}$ School of Management and Technology, Polytechnic Institute of Santarém, \\ Complexo Andaluz, Apartado 295, 2001-904 Santarém, Portugal \\ ${ }^{2}$ Department of Finance, Insurance and Real Estate, \\ Fogelman College of Business and Economics, University of Memphis, \\ Memphis, TN 38152-3120, USA \\ ${ }^{3}$ Caixa Geral de Depósitos/Sardoal, \\ Rua 5 de Outubro, 23, 2230-121 Sardoal, Portugal \\ ${ }^{4}$ Department of Business Administration, \\ Faculty of Economics, University of Vlora "Ismail Qemali", \\ Sheshi Pavarësia, 9401 Vlorë, Albania \\ E-mails: ${ }^{1}$ fernando.ferreira@esg.ipsantarem.pt or fernando.ferreira@memphis.edu \\ (corresponding author); ${ }^{2}$ rspahr@memphis.edu; ${ }^{3}$ irina.diogo.gavancha@cgd.pt; \\ 4amalia.cipi@univlora.edu.al
}

Received 11 December 2011; accepted 13 February 2012

\begin{abstract}
Credit-scoring becomes increasingly important in poor economies and recessions. Decreasing liquidity due to reduced access to both money and debt markets has induced banks to impose restrictions on offering credit, including credit for mortgage loans. In this paper we analyze the internal rating system used by one of the top-five banks in Portugal, and propose a methodological framework which, based on an application of the Delphi technique, allows adjusting trade-offs among evaluation criteria and provides decision makers with a fairer, more accurate and transparent mortgage risk evaluation system.

Keywords: credit-scoring, Delphi technique, evaluation criteria, mortgage loan, risk analysis, trade-offs.

Reference to this paper should be made as follows: Ferreira, F. A. F.; Spahr, R. W.; Gavancha, I. F. M. D.; Çipi, A. 2013. Readjusting trade-offs among criteria in internal ratings of credit-scoring: an empirical essay of risk analysis in mortgage loans, Journal of Business Economics and Management 14(4): 715-740.
\end{abstract}

JEL Classification: C44, G21, M10. 


\section{Introduction}

Housing acquisition is generally the largest investment for most households, thus requiring careful analysis from all economic agents involved in the transaction (e.g. individuals, families, credit institutions). Since most families do not have the capital available to outright purchase a residence, mortgages in the form of bank loans are the most common solution for home acquisition. However, because of the effects of the current economic conjuncture, regulators have been encouraging banks to develop more sophisticated risk models with the purpose of "better quantifying the financial risks they face and assigning the necessary economic capital" (Lopez, Saidenberg 2000: 152). From this standpoint, remarkable progress has occurred recently in terms of credit risk modeling (for a categorized literature review, see Altman, Saunders 1998; Crook et al. 2007; Suhobokov 2007; Ince, Aktan 2009; Yu et al. 2009; Wang et al. 2011). Still, as recognized by many (e.g. Altman, Saunders 1998; Lopez, Saidenberg 2000; Doumpos, Zopounidis 2001; Doumpos et al. 2002; Mačerinskienè, Ivaškevičiūte 2008; Thomas 2009; Twala 2010), despite the strengths and widespread application of current methodologies, models, techniques and/or simple applications, each solution has specific drawbacks where clarification is required on a number of issues. For example, Ferreira et al. (2011) observed a lack of transparency in the way trade-offs among evaluation criteria are made explicit. From this perspective, this paper analyzes the internal rating system used by one of the top-five banks operating in Portugal, in terms of mortgage loan risk analysis. In fact, based on a Delphi panel composed of mortgage loan risk analysts from the bank being analyzed, this paper contributes to the credit-scoring literature by formulating an approach allowing for the readjustment of trade-offs among criteria and introducing additional transparency in the decision-making process.

Methodologically, we analyze the major modalities of mortgages in Portugal, and the major performance measures included in the bank's current system, allowing for a better understanding of and insight into the current mortgage process. Understanding the mortgage process is extremely important for the application of the Delphi technique and for promoting consensus among panel members, which may ultimately lead to new scrutiny among evaluation criteria, and to a fairer mortgage risk evaluation system. To the best of our knowledge, this constitutes a novel approach in the credit-scoring literature.

The remainder of the paper is structured as follows. Section 2 reviews existing literature on mortgage lending, credit scoring and importance for a country's economy. Section 3 describes the current system used by the bank, and sections 4,5 and 6 discuss the application of the Delphi technique, its results in terms of trade-offs readjustment, and the advantages and disadvantages of our analysis, respectively. Section 7 tests the "new" model, and section 8 concludes the paper.

\section{The relevance of mortgage loan for a country's economy}

As mentioned previously, buying a home is generally the largest investment for most households, and since most families have only a small portion of the capital required to purchase a home, bank mortgage loans (ML) are the most common solution for 
home acquisition. Historically, mortgage lending has allowed the private sector to satisfy stakeholders' interests, and stimulate the economy because it allows for: (1) the development of the housing construction industry, which secondarily supports related business activities; (2) direct and indirect stimuli of job growth, contributing to a higher employment rate; (3) expansion of the financial services industry; (4) productivity increases by providing a demand for domestically supplied goods and services that meet existing housing needs; (5) increases in the circulation of money among economic agents; and (6) significant contribution to the country's Gross Domestic Product (GDP) (i.e. wealth-generating economic conditions and increasing money circulation contribute to GDP growth). In this sense, mortgage lending has a significant impact on a country's economy, not only because it stimulates increased household consumption (Lima et al. 1995) but also because it offers the possibility to reduce unemployment, which, in turn, boosts productivity and generates greater economic wealth by increasing money circulation and the need for more products and/or services. Furthermore, as pointed out by Mari and Renò (2005: 83), the importance of ML for a country's economy is based on a reciprocal influence (i.e. in a slumping economy, there are no positive impacts on real estate). Quoting the authors, "the market for mortgage loans is of primary importance in any developed country, and its quality is directly connected to the quality of the whole economy".

\subsection{Mortgage lending in Portugal}

Renting has always be an unfavourable option in the Portuguese housing market due to, among other reasons, legislation and heavy bureaucracy (for further details, see Constantino 2011). As such, home purchase was the preferable option during recent decades, and banks, pressured by chronically low margins, turned to mortgage lending. As illustrated in Figure 1, mortgage loans represent $46 \%$ of the credit portfolio in Portugal.

The scenario presented in Figure 1 can also be explained by the current economic conjuncture, which denotes a reduced employment rate, salary reductions and increasing individual and corporate taxes. Thus, because of reduced income and less personal capital, people have no option other than to request mortgage loans. Nonetheless, because Portuguese banks have been losing access to money and medium-term and longterm debt markets, they have been following the directions of the European Central Bank (ECB) and imposing severe restrictions on access to credit. Constantino (2011)

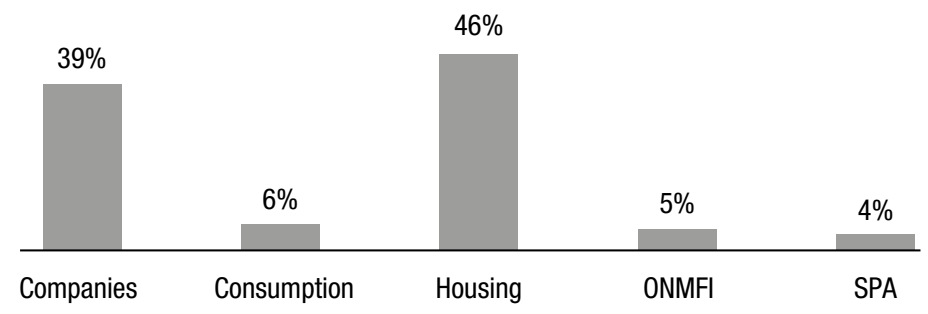

Fig. 1. Credit portfolio in Portugal Source: Constantino (2011, adap.). 
observes that these restrictions negatively impact the Portuguese economy, but became more a requirement than an option. Table 1 presents the existing four pillars on which the mortgage credit typology is based in Portugal (i.e. general regime, disabled regime, subsidized regime, and young subsidized regime).

For the proper functioning of the four regimes of mortgage loans identified in Table 1, a few features need to be clarified. These features are related to the interest rate, type of reimbursement, and guarantees (Table 2).

Table 1. Mortgage loan regimes and characteristics in Portugal

\begin{tabular}{|c|c|c|}
\hline $\begin{array}{l}\text { General } \\
\text { Regime }\end{array}$ & $\begin{array}{l}\text { Disabled } \\
\text { Regime }\end{array}$ & $\begin{array}{c}\text { Subsidized and Young Subsidized } \\
\text { Regime }\end{array}$ \\
\hline $\begin{array}{l}\text { Integrates households } \\
\text { wishing to purchase } \\
\text { housing under the } \\
\text { Decree-Law } 349 / 98 \\
\text { of November } 11^{\text {th }} 1998 \text {. }\end{array}$ & $\begin{array}{l}\text { Is intended for individuals } \\
\text { with a disability degree } \\
\text { equal or greater than } \\
60 \% \text {, allowing access } \\
\text { to a cheaper acquisition } \\
\text { system, regulated by the } \\
\text { Decree-Law } 43 / 76 \text { of } \\
\text { January } 20^{\text {th }} \text { and } \\
202 / 96 \text { of October } 23^{\text {rd }} \text {. }\end{array}$ & $\begin{array}{l}\text { Previously regulated by Article } \\
13^{\text {th }} 349 / 98 \text { of November } 11^{\text {th }} \\
\text { and by Regulation } 1177 / 2000 \\
\text { of December } 15^{\text {th }} \text {, this regime changed } \\
\text { after September } 30^{\text {th }} 2002 \text {, remaining } \\
\text { the imposition of proof on the number } \\
\text { of household members. }\end{array}$ \\
\hline
\end{tabular}

Source: Banco de Portugal (2011a).

Table 2. Mortgage loan interest rate, reimbursement and guarantees

\begin{tabular}{lll}
\hline & Modalities & \multicolumn{1}{c}{ Description } \\
\hline Interest Rate & Fixed & $\begin{array}{l}\text { Interests vary according to variations } \\
\text { of the indexed rate }\end{array}$ \\
\cline { 2 - 3 } & Mrogressive & $\begin{array}{l}\text { Interests increase in accordance with } \\
\text { the time course } \\
\text { Combination of regimes }\end{array}$ \\
\hline Reimbursement & Pattern & The French method is applied \\
\cline { 2 - 3 } & Grace Period & $\begin{array}{l}\text { Period of time where there is payment } \\
\text { of interests without capital amortization }\end{array}$ \\
\cline { 2 - 3 } & Deferred Capital & $\begin{array}{l}\text { Part of capital in debt is postponed to } \\
\text { the end of the loan }\end{array}$ \\
\hline Guarantees & Hypothec & $\begin{array}{l}\text { Serves as a guarantee in case of absence } \\
\text { of debt payments }\end{array}$ \\
\cline { 2 - 3 } & Bail & $\begin{array}{l}\text { A third economic agent will pay the debt } \\
\text { in case of default }\end{array}$ \\
\cline { 2 - 3 } & Life Insurance & $\begin{array}{l}\text { Covers the loan in case of disability or death } \\
\text { Con }\end{array}$ \\
\hline
\end{tabular}

Source: Banco de Portugal (2011b). 


\subsection{The importance of mortgage loan risk evaluation}

After framing the existing regimes of ML in Portugal, it is important to understand how the decision process works, considering several administratively pre-established weighted evaluation criteria. It is important to bear in mind that these criteria (and respective weights) are the basis of the evaluation of a loan request, and ultimately will support the decision of approving or disapproving the loan. There are three major phases of the mortgage loan evaluation process: request entry, process analysis, and decision.

Detailed explanations of the different phases of the process are beyond the scope of this paper. However, in broad terms, the process begins with a request entry, where clients formalize the request for the desired mortgage loan. In order to define the customer profile, several documents are included in the process: (1) identity card; (2) taxpayer number; (3) receipts of the last three Pay periods; (4) IRS and settlement note; (5) bank account balance; (6) plan of the house, and building handbook (required for property valuation); and (7) building license (necessary if the aim is to build). In the second phase of the process (i.e. process analysis), the level of risk associated with the client is determined. To this end, banks have a fundamental tool for the risk evaluation process, called Consultation of Credit Responsibilities (CCR), which is provided by the Banco de Portugal (BP) (i.e. Portuguese Central Bank), and allows banks to access accurate and reliable information on the client's profile, given the client's written permission. Among other things, this CCR operational tool allows financial institutions to define the level of responsibility (borrower/guarantor), the credit situation (degree of payment compliance), the typology of the financial product, and the type of guarantee (see again Table 2). Analyzing the customer's profile is just one of the components of the evaluation process. Other components consider the evaluation of the property. The third phase of the process (i.e. decision) follows from the composite results among the different components of the process. Thus, banks have internal ratings for credit-scoring, which provides supporting evidence for the final lend or reject decision.

\subsection{Internal rating system for credit-scoring}

The different phases of a mortgage loan evaluation process briefly presented in the previous subsection help in assessing the risk of the customer, and/or the credit operation. Obviously, different risk levels will require different interest rate spreads. Based on the Basel directive, spreads should be defined within the scope of limiting the risk for banks. Correspondingly, banks have conceived and developed internal rating systems for credit-scoring, which measures the risk of each credit transaction. In the Portuguese financial system, the most common evaluation criteria included in the internal rating systems are:

- Loan-To-Value (LTV): Balances the funding with the guarantee associated to the operation;

- Rate of Effort: Calculates the customer's capacity for paying the loan;

- Customer's Age: Considered a key factor not only for the credit institution but also for the insurance company that will provide the guarantee; 
- Professional Status: Considers knowledge of the client's employment situation;

- Household: Indicates the funds available to meet the primary needs of the client;

- Involvement: Assumes a cross-selling perspective and contextualizes the client by providing information on his/her bank account average balance, existence of financial investments, credit cards, and other existing banking products.

A composite of the above criteria results in either a "favourable" or "unfavourable" lending decision. In practice, these outcomes are based on a "1" to "10" scale, which also determines the interest rate spread (further details are presented in section 3). In Portugal, due to the current social and economic situation, mortgage lending underwriting requirements imposed by financial institutions tend to be severe. Among others, these requirements include the reduction of the LTV and the adoption of long-term loans. The associate spreads and indexed rates also tend to be high, and often unaffordable for most families.

\section{The current model for mortgage risk evaluation}

Regardless of how financial institutions innovate and modify the modalities of mortgage loans, this credit underwriting process, and respective calculation of the risk associated with each client, usually is based on similar evaluation criteria. In the next two subsections, we specifically describe the internal rating system for mortgage loans creditscoring used by one of the top-five banks operating in Portugal. Insights of the analysis will assist in understanding how the decision process works, and the way composite results from the criteria are made explicit.

\subsection{Criteria generally considered}

As previously discussed, the internal ranking system for credit-scoring is a tool that helps banks in evaluating underwriting risk of mortgage loan requests. However, the criteria presented in subsection 2.3 are usually insufficient for an accurate risk evaluation. As such, banks are forced to consider a wider range of information (i.e. more information about a client will generally result in a more reliable underwriting credit score). After due consideration of the variables, two types of analysis should be performed: documentary analysis and behavioral analysis. Documentary analysis is a study performed by financial institutions using data collected from the documents submitted by the client. This includes:

- IRS/Settlement Note: Allows knowing the number of household elements, and calculating the rate of effort;

- BP Responsibilities: This item also enables calculation of the rate of effort based on classified information;

- Property Assessment: Allows calculating the LTV;

- Banking Extracts: Allows calculating the average balance of the client's bank account, and checking if the client is (or not) averse to savings. This also allows the institution to ascertain the ability of self-financing of their customers;

- Employer Declaration: Reveals the type of contract, in terms of job stability, established between the client and the respective employer. 
The behavioral analysis is used in conjunction with the documentary analysis to identify the client's age, degree of involvement with the financial institution (i.e. existence of low, intermediate or high number of products utilized, such as: debit/credit cards; insurances and saving accounts and/or deposits) and other client features. To illustrate the current model of analysis, Table 3 presents the clusters of variables (and aggregated weights) included in the decision process.

Table 3. Clusters of variables and aggregated weights of the current credit-scoring model

\begin{tabular}{llc}
\hline \multicolumn{1}{c}{ Cluster } & \multicolumn{1}{c}{ Variables } & Aggregated Weight \\
\hline Customer Characteristics & $\begin{array}{l}\text { Profession, Employment Situation, } \\
\text { Marital Status, Age and Household }\end{array}$ & 0.30 \\
\hline Customer Behavior & $\begin{array}{l}\text { Cross-selling, Deposit Portfolio, } \\
\text { Average Balance }\end{array}$ & 0.15 \\
\hline Customer Documental Analysis & $\begin{array}{l}\text { Rate of Effort, Responsibilities } \\
\text { in BP, LTV, Existence of Guarantors }\end{array}$ & 0.50 \\
\hline Other Variables & $\begin{array}{l}\text { Environmental Variables } \\
\text { (not specifically defined) }\end{array}$ & 0.05 \\
\hline
\end{tabular}

Source: Administrative information.

The information presented in Table 3 improves the understanding of the process because, among other things, it allows the conclusion that the customer documental analysis, which includes variables such as rate of effort and LTV, is the cluster with major impact on credit evaluation.

\subsection{Limitations of the current credit-scoring system}

Table 3 demonstrates current mortgage risk assessment models applying an unknown number of related criteria that sometimes results in inconsistent conclusions (i.e. unknown variables may be allocated to the Other Variables category). It is important to identify major limitations of the current evaluation model, clarify the evaluation mechanisms and introduce transparency in the decision-making process. Figure 2 presents the major limitations of the current credit-scoring system for mortgage loans.

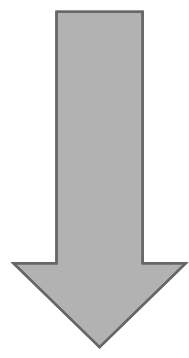

- Considering that weights are independent of the geographic area and, thus, common to all bank branches of the bank, there is a real possibility of inappropriate weighting.

- There is no prior knowledge of how trade-offs among evaluation criteria have been defined, which reveals lack of transparency and makes some of the final decisions difficult to understand.

- There is no flexibility in terms of trade-offs.

- Unable to consider behavioral variables.

Fig. 2. Limitations of the current credit-scoring system Source: Administrative information. 
As previously discussed, the limitations of the current credit-scoring system contribute to possible incoherent predictions that should be analyzed. The current mortgage scoring system is based on a " 1 " to " 10 " scale where a credit approval takes place when credit scores are between " 1 " and " 5 ", and a credit refusal occurs when credit scorings are strictly above "5". However, a client may score " 1 " (i.e. very low-risk), but if the bank is aware of anomalies, such as if a client does not respect his/her commitments, then the mortgage loan should not be approved.

Given that credit risk assessment includes variables that are translated into ratios, and ratios are usually lagged indicators (Ferreira et al. 2011), it is important to recognize that results may be poor predictors of future reality. Based on this premise, the following sections describe how the Delphi methodology may be applied to allow trade-off readjustments, and to incorporate the knowledge and experience of bank professionals in the decision-making process. We are confident that our process-oriented framework will result in a more accurate, fairer and more transparent mortgage evaluation system.

\section{Methodological framework}

\subsection{Brief background of the Delphi technique}

According to Dalkey and Helmer (1963), Ferreira (2003), Hsu and Sandford (2007), among others, the Delphi technique was developed in the 1950s by Norman Dalkey, Olaf Helmer, and a team of collaborators at the RAND Corporation to solve problems for the USA Air Force.

The Delphi technique begins with the development of an individual survey, which should be completed by a number of individuals considered experts on the topic under consideration. As argued by Ferreira and Monteiro Barata (2011: 246), the method is based on "a well-established sequence of successive individual questions supplemented with information and advice, which permits correcting the first stages of the process. [...] it is a tool, which, under certain parameters, enables consensus. [...] and is based on the rational principle that ' $n$ ' human minds are better than one when confronting the lack of precise knowledge about a certain subject". In this sense, the technique should allow for consensual and realistic results, and its basic principles are anonymity, controlled feedback, and statistical treatment of the responses. See Figure 3 for a better understanding of the Delphi technique and its operational structure (for further details, see also Dalkey, Helmer 1963; Dalkey 1969; Ferreira 2003; Šečkutė, Pabedinskaite 2003; Hsu, Sandford 2007; Fernandes 2010; Ferreira, Monteiro Barata 2011).

As previously mentioned, the results of the Delphi method are presented through statistical formulation. As indicated in Ferreira (2003), the results are defined by a function: $G=G_{j}(I, E, R)$, which reflects the response of a given group $G_{j}$ to a certain event $E$, where $I$ is the number of individuals, $E$ is the event space (discrete or continuous), and $R$ is the domain of answers, which is reflected in an estimation for each event and individual of the group. It should be noted, however, that this formulation may be based on different components of statistics, such as measures of central tendency (i.e. mean, median, mode or quartiles) or dispersion (i.e. standard deviation, variance or semi-interquartile amplitude). 

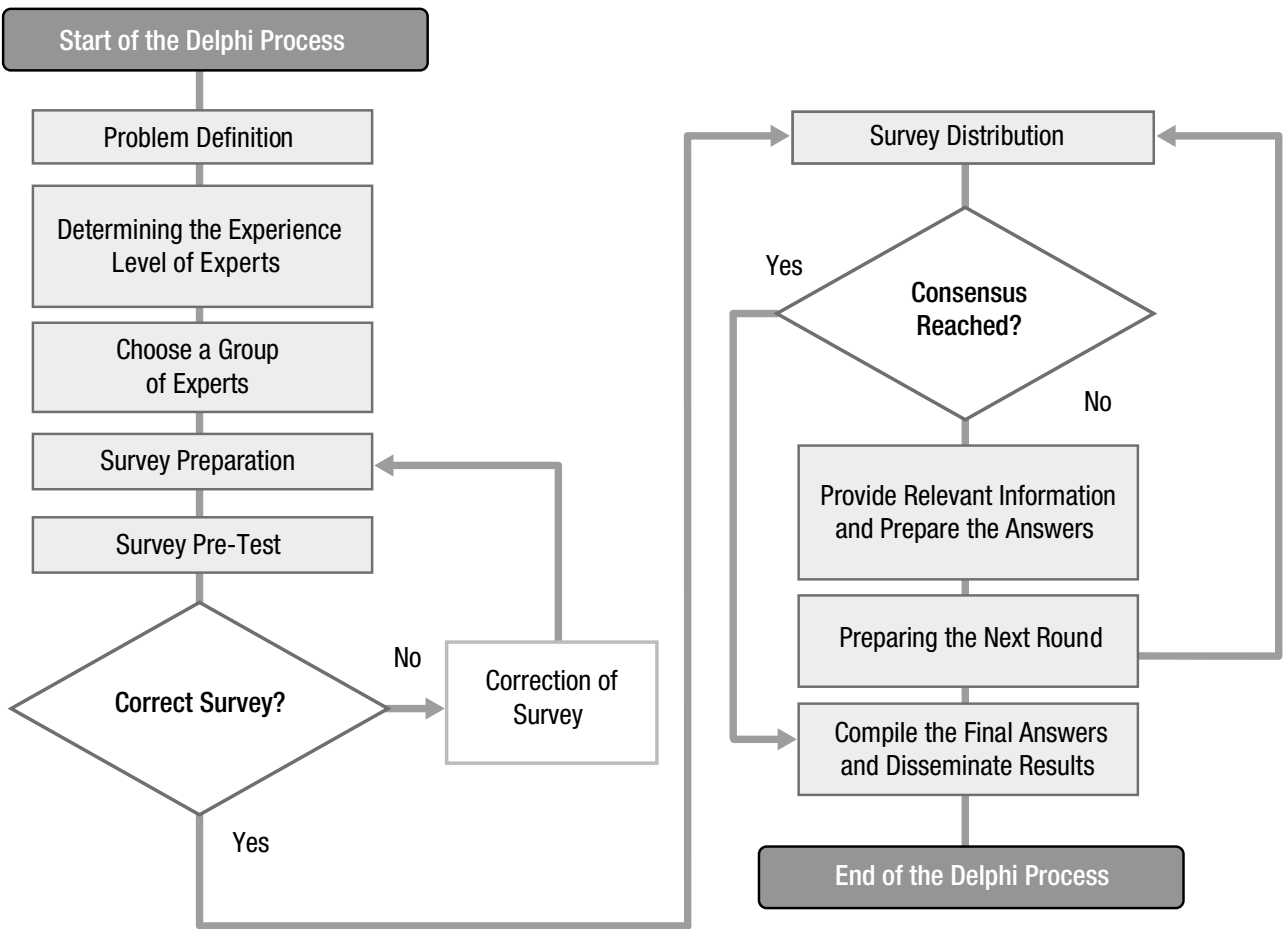

Fig. 3. Structure of the Delphi Method Source: Zapata, in Ferreira (2003, adap.).

\subsection{Strengths and weaknesses of the Delphi technique}

As in other methods, the Delphi technique has strengths and weaknesses. Figure 4 presents some of the advantages and shortcomings of the Delphi technique, as suggested in the literature (e.g. Dalkey, Helmer 1963; Dalkey 1969; Ferreira 2003; Šečkute, Pabedinskaite 2003; Hsu, Sandford 2007; Fernandes 2010; Ferreira, Monteiro Barata 2011).

Ferreira and Monteiro Barata (2011) describe how the Delphi technique has been applied in a wide range of different areas, such as: politics, economics, public finance, and operations management. It is a tool that allows for the treatment of several different themes, boosting knowledge among the participants through a feedback loop that allows reflection on the early judgments and, when needed, correcting previous answers. The survey is individual and confidential, allowing participants to express themselves without the influence of the organization hierarchy. In accordance with the Joint Research Centre (JRC 2011), the Delphi technique may be applied in isolation or associated with other methodologies, and it should be noted that the process not only allows organizations to be able to identify existing problems and provide possible resolutions but also to create corporate strategies based on the knowledge retained from the respondents' answers. 


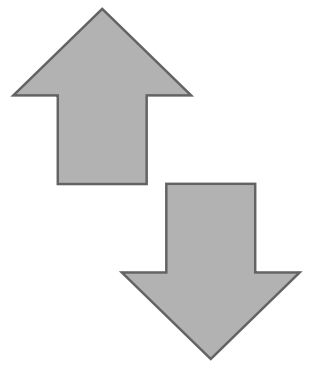

- Allows the treatment of different topics;

- Opinions are not judged;

- Does not require physical presences.

- Experts are chosen;

- Answers maybe indirectly persuaded;

- "Poor" elaboration of the survey.

Fig. 4. Advantages and shortcomings of the Delphi method

On the negative side, experts with certain expertise may not be readily available, thus often limiting the scope of the applications. Another negative factor regards the application of the survey, where questions may be misunderstood by the respondents, thus jeopardizing the results simply because the technique does not require the physical presence of the agents involved in the process. Also, the statistical treatment of the answers provided to the respondents after each round may be considered an influencing factor (i.e. an individual may feel forced to answer according to the responses of the group). Lastly, the existence of rounds also means that respondents may no longer wish to participate, either because the survey is always the same or because it becomes time-consuming.

In the next section, we present and discuss the results achieved with a Delphi panel in terms of trade-offs readjustment in a mortgage loan credit-scoring system.

\section{Results analysis}

This research was conducted after the intervention of the so called "Troika" (i.e. IMFECB-EU), which restructured the mortgage loan approval into a more discerning and meticulous process. For convenience, the initial Delphi panel was composed of 15 bank experts (i.e. mortgage loan risk analysts with senior responsibilities), who operate in Santarém, Portugal. As shown in Figure 5, after the first round, the number of panel members was reduced to 13 and, after the second round, only 11 members provided their responses to the survey. Considering that there is no ideal number of experts for the application of the Delphi technique (Ferreira, Monteiro Barata 2011), responses from the 11 members in the final round provide the basis of our analysis.

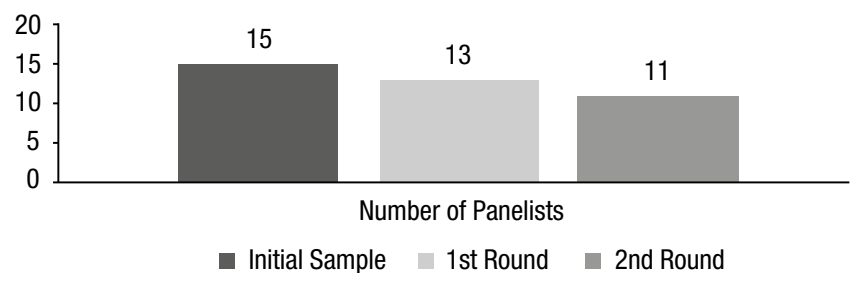

Fig. 5. Number of panel elements per round Source: Data collected through the Delphi cpplication. 
It should be noted that the reduction of the number of panel members is anticipated in the Delphi methodology. Several factors can cause this reduction (cf. subsection 4.2). However, in our case, the reduction of the number of panel members resulted from the survey being the same in each round (see Appendixes 1 and 2). Moreover, in some cases, there were misunderstandings in the interpretation of the responses (i.e. the sum of the weights exceeded $100 \%$ ), and, as such, those surveys were eliminated.

\subsection{Analysis and interpretation of customer characteristics}

The objective of the first part of the survey was to determine the degree of importance given by the panelists to the customers' characteristics, particularly in terms of profession, employment status, marital status, age and household. Based on data collected from the panel of experts, we found that only two of the five variables are given high importance (i.e. the 11 experts determined that employment situation (or status) (with mean of $11.41 \%$ and median of $10 \%$ ), and profession (with mean of $8.82 \%$ and median of $8 \%$ ) are the elements that, in this category, should contribute more to the credit risk analysis) (Table 4).

Table 4. Analysis of customer characteristics

\begin{tabular}{lccccc}
\hline \multicolumn{1}{c}{ Variables } & $\mathrm{N}$ & Mean \% & Median \% & $\begin{array}{c}\text { Standard } \\
\text { Deviation \% }\end{array}$ & $\begin{array}{c}\text { Coefficient of } \\
\text { Variation \% }\end{array}$ \\
\hline Profession & 11 & 8.82 & 8.0 & 4.3 & 0.49 \\
\hline $\begin{array}{l}\text { Employment } \\
\text { Situation }\end{array}$ & 11 & 11.41 & 10.0 & 6.14 & 0.54 \\
\hline Marital Status & 11 & 1.68 & 1.5 & 1.4 & 0.83 \\
\hline Age & 11 & 2.09 & 1.0 & 2.99 & 1.43 \\
\hline Household & 11 & 1.36 & 1.0 & 1.45 & 1.07 \\
\hline
\end{tabular}

Source: Data collected through the Delphi application.

Based on Table 4, one may assume that profession and employment situation/status are among the most important criteria due to the fact that job stability supports customers' commitments better (i.e. a customer with an "essential" profession (e.g. medical doctor), will tend to reveal higher levels of stability).

\subsection{Analysis and interpretation of customer behavior}

The second part of the survey analyzed customer behavior and considered the following variables: cross-selling, deposit portfolio and average balance. Based on data presented in Table 5, we can estimate the importance of cross-selling.

According to the panelists, cross-selling is an important factor (mean of $10.59 \%$ and median of $10 \%$ ) (i.e. the greater the portfolio of products that a customer utilizes the greater the potential profit margin for the financial institution). It should be noted, however, that deposit portfolio (with mean of $6.05 \%$ and median of $5 \%$ ), and average bal- 
Table 5. Analysis of customer behavior

\begin{tabular}{lccccc}
\hline \multicolumn{1}{c}{ Variables } & $\mathrm{N}$ & Mean \% & Median \% & $\begin{array}{c}\text { Standard } \\
\text { Deviation \% }\end{array}$ & $\begin{array}{c}\text { Coefficient of } \\
\text { Variation \% }\end{array}$ \\
\hline Cross-selling & 11 & 10.59 & 10.0 & 4.16 & 0.39 \\
\hline Deposit Portfolio & 11 & 6.05 & 5.0 & 2.43 & 0.40 \\
\hline Average Balance & 11 & 7.23 & 7.5 & 3.92 & 0.54 \\
\hline
\end{tabular}

Source: Data collected through the Delphi application.

ance (with mean of $7.23 \%$ and median of $7.5 \%$ ) should not be neglected, because a client with sizable positive average balance represents a favorable indicator and induces financial capacity to fulfill responsibilities.

\subsection{Analysis and interpretation of customer documents}

The third part of the survey carries out a documental analysis, particularly in terms of rate of effort; responsibilities in BP, LTV and existence of guarantors. Table 6 allows us to conclude that the higher impact variable is the rate of effort.

Table 6. Customer documental analysis

\begin{tabular}{lccccc}
\hline \multicolumn{1}{c}{ Variables } & $\mathrm{N}$ & Mean \% & Median \% & $\begin{array}{c}\text { Standard } \\
\text { Deviation \% }\end{array}$ & $\begin{array}{c}\text { Coefficient of } \\
\text { Variation \% }\end{array}$ \\
\hline Rate of Effort & 11 & 19.45 & 20.0 & 6.82 & 0.35 \\
\hline Responsibilities in BP & 11 & 12.45 & 12.0 & 4.06 & 0.33 \\
\hline LTV & 11 & 11.95 & 10.0 & 4.25 & 0.36 \\
\hline $\begin{array}{l}\text { Existence } \\
\text { of Guarantors }\end{array}$ & 11 & 3.09 & 4.0 & 2.26 & 0.73 \\
\hline
\end{tabular}

Source: Data collected through the Delphi application.

It is widely known that a guarantor is a person or firm that endorses an agreement to guarantee/insure that commitments made by a client will be fulfilled, and assumes liability if the client fails to fulfill those commitments. However, based on Table 6, we may observe that the existence of guarantors (with mean of 3.09\% and median of $4 \%$ ) is the variable that experts suggest has the least impact. This observation is supported by the fact that, frequently, guarantors are only associated with credit operations for representing a comfort margin, and not because there is lack of funds from borrowers. The $L T V$ is seen as an important factor (with mean of $11.95 \%$ and median of $10 \%$ ). In fact, this variable is essential because a low LTV ratio will facilitate a possible sale in case of default and foreclosure (e.g. auction). Accordingly, the higher the LTV ratio, the greater the importance of the guarantee. The rate of effort (with mean of $19.45 \%$ and median of 20\%) seems to be the most important ratio for the Delphi panelists. 


\subsection{Analysis and interpretation of the environment}

The fourth and final part of the survey analyzed the impact on credit scoring of the economic environment, and is represented by two variables: economic situation of the country and political situation of the country. It should be noted that the experts find this is an area of minor importance (Table 7).

Table 7. Analysis of environmental variables

\begin{tabular}{lccccc}
\hline \multicolumn{1}{c}{ Variables } & $\mathrm{N}$ & Mean \% & Median \% & $\begin{array}{c}\text { Standard } \\
\text { Deviation \% }\end{array}$ & $\begin{array}{c}\text { Coefficient of } \\
\text { Variation \% }\end{array}$ \\
\hline $\begin{array}{l}\text { Economic Situation of } \\
\text { the Country }\end{array}$ & 11 & 2.39 & 1.5 & 2.8 & 1.17 \\
\hline $\begin{array}{l}\text { Political Situation } \\
\text { of the Country }\end{array}$ & 11 & 1.44 & 1.0 & 1.31 & 0.91 \\
\hline
\end{tabular}

Source: Data collected through the Delphi application.

Although experts have not attributed great importance to these two variables (i.e. economic and political situation of the country) (with mean of $2.39 \%$ and $1.44 \%$ and median of $1.5 \%$ and $1 \%$ respectively), it is worth mentioning that financial institutions will be required to use these factors in analyzing credit risk because of the IMF bringing more restrictive rules for the Portuguese banking system (for more discussion on situational circumstances and non-financial factors, see Avery et al. 2004; Grunert et al. 2005). The theoretical framework proposed in this study, together with information collected from the application of the Delphi method, allows the development of a modified model for credit risk analysis.

\section{Readjustment of weights}

Based on the progress achieved with the panel of experts, it is possible to readjust credit scoring weights and develop a modified model for mortgage risk evaluation. For comparison, Table 8 shows the current weights that support the credit evaluation decisions in the target bank, while Table 9 summarizes the results obtained from the Delphi panel.

Table 8. Table of current trade-offs

\begin{tabular}{lc}
\hline \multicolumn{1}{c}{ Variables } & Values $\%$ \\
\hline Profession & 12.00 \\
\hline Employment Situation & 8.00 \\
\hline Marital Status & 3.75 \\
\hline Age & 2.50 \\
\hline Household & 3.75 \\
\hline Cross-selling & 10.00 \\
\hline
\end{tabular}


End of Table 8

\begin{tabular}{lc}
\hline \multicolumn{1}{c}{ Variables } & Values \% \\
\hline Deposit Portfolio & 2.50 \\
\hline Average Balance & 2.50 \\
\hline Rate of Effort & 15.00 \\
\hline Responsibilities in BP & 15.00 \\
\hline LTV & 15.00 \\
\hline Existence of Guarantors & 5.00 \\
\hline Economic Situation of the Country & 2.50 \\
\hline Political Situation of the Country & 2.50 \\
\hline
\end{tabular}

Source: Administrative information.

Table 9. Statistics of the $2^{\text {nd }}$ round

\begin{tabular}{lccccc}
\hline \multicolumn{1}{c}{ Variables } & N & Mean \% & Median \% & $\begin{array}{c}\text { Standard } \\
\text { Deviation \% }\end{array}$ & $\begin{array}{c}\text { Coefficient of } \\
\text { Variation \% }\end{array}$ \\
\hline Profession & 11 & 8.82 & 8.0 & 4.3 & 0.49 \\
\hline Employment Situation & 11 & 11.41 & 10.0 & 6.14 & 0.54 \\
\hline Marital Status & 11 & 1.68 & 1.5 & 1.4 & 0.83 \\
\hline Age & 11 & 2.09 & 1.0 & 2.99 & 1.43 \\
\hline Household & 11 & 1.36 & 1.0 & 1.45 & 1.07 \\
\hline Cross-selling & 11 & 10.59 & 10.0 & 4.16 & 0.39 \\
\hline Deposit Portfolio & 11 & 6.05 & 5.0 & 2.43 & 0.40 \\
\hline Average Balance & 11 & 7.23 & 7.5 & 3.92 & 0.54 \\
\hline Rate of Effort & 11 & 19.45 & 20.0 & 6.82 & 0.35 \\
\hline Responsibilities in BP & 11 & 12.45 & 12.0 & 4.06 & 0.33 \\
\hline LTV & 11 & 11.95 & 10.0 & 4.25 & 0.36 \\
\hline Existence of Guarantors & 11 & 3.09 & 4.0 & 2.26 & 0.73 \\
\hline $\begin{array}{l}\text { Economic Situation } \\
\text { of the Country }\end{array}$ & 11 & 2.39 & 1.5 & 2.8 & 1.17 \\
\hline $\begin{array}{l}\text { Political Situation } \\
\text { of the Country }\end{array}$ & 11 & 1.44 & 1.0 & 1.31 & 0.91 \\
\hline
\end{tabular}

Source: Data collected through the Delphi application.

As previously described, credit scoring allows us to calculate scores between "1" and "10". Given a score between "1" and "5", the credit decision should be favourable; otherwise the credit decision should be unfavourable. Nonetheless, one should bear in mind that, when analyzing variable-by-variable, each client generates different results. Therefore, considering the existence of partial ratings, Table 10 provides a few guide- 
lines/considerations that a financial institution may follow in order to calculate accurate partial (and overall) scores.

As may be easily deduced, the final (or overall) score corresponds to the sum of the partial weighted scores. As such, for each variable there is a weight which will influence the final decision. Consequently, we must explain that, depending on each variable, the assessments may change. Table 11 presents the trade-offs of both systems, which facilitates a direct comparison.

Table 10. Examples of partial ratings

\begin{tabular}{|c|c|c|}
\hline Rate of Effort & LTV & Cross-Selling \\
\hline $\begin{array}{l}\text { Favorable } \\
<35 \% \\
\text { Score } 1-3\end{array}$ & $\begin{array}{l}\text { Favorable } \\
<50 \% \\
\text { Score } 1-2\end{array}$ & $\begin{array}{l}\text { Customer who holds several financial products } \\
\text { and households his/her salary in the institution } \\
\text { Score } 1-3\end{array}$ \\
\hline $\begin{array}{l}\text { Favorable } \\
{[35 \%-45 \%]} \\
\text { Score } 4-5\end{array}$ & $\begin{array}{l}\text { Favorable } \\
{[50 \%-90 \%]} \\
\text { Score } 3-5\end{array}$ & $\begin{array}{l}\text { Customer who holds a single bank account } \\
\text { and households his/her salary in the institution } \\
\text { Score } 4-5\end{array}$ \\
\hline $\begin{array}{l}\text { Unfavourable } \\
>45 \% \\
\text { Score } 6-10\end{array}$ & $\begin{array}{l}\text { Unfavourable } \\
>90 \% \\
\text { Score } 6-10\end{array}$ & $\begin{array}{l}\text { Customer who does not have any relationship } \\
\text { with the institution } \\
\text { Score } 6-10\end{array}$ \\
\hline
\end{tabular}

Source: Administrative information.

Table 11. Standard trade-offs vs. Delphi trade-offs

\begin{tabular}{llcc}
\hline \multicolumn{1}{c}{ Variables } & $\mathrm{N}$ & Standard Values \% & Delphi Mean Values \% \\
\hline Profession & 11 & 12.00 & 8.82 \\
\hline Employment Situation & 11 & 8.00 & 11.41 \\
\hline Marital Status & 11 & 3.75 & 1.68 \\
\hline Age & 11 & 2.50 & 2.09 \\
\hline Household & 11 & 3.75 & 1.36 \\
\hline Cross-selling & 11 & 10.00 & 10.59 \\
\hline Deposit Portfolio & 11 & 2.50 & 6.05 \\
\hline Average Balance & 11 & 2.50 & 7.23 \\
\hline Rate of Effort & 11 & 15.00 & 19.45 \\
\hline Responsibilities in BP & 11 & 15.00 & 11.95 \\
\hline LTV & 11 & 15.00 & 3.09 \\
\hline Existence of Guarantors & 11 & 5.00 & 2.39 \\
\hline Economic Situation of the Country & 11 & 2.50 & 1.44 \\
\hline Political Situation of the Country & 11 & 2.50 &
\end{tabular}

Source: Administrative information and data collected through the Delphi application.

Based on the information in Table 11, the more pronounced variations between the two models are associated with variables that have more weight in the final decision, and it 
should be highlighted that experts give more emphasis to variables such as the rate of effort. The "new" or modified model is tested in the following section.

\section{Testing the "New" model}

Mortgage loan data are used in testing the "new" model. For testing purposes, Table 12 presents information from an anonymous client.

Before readjusting the weights, it is necessary to know how the bank under analysis obtains the values of the partial ratings. Table 13 demonstrates the mechanism used, which is based on the information provided by the bank's customers.

Table 12. Data from an anonymous customer

\begin{tabular}{ll}
\hline Profession & Customer with a profession in a stable industry \\
\hline Employment Status & Customer with three years of permanent employment \\
\hline Marital Status & Single customer \\
\hline Age & $25-35$ \\
\hline Household & 1 Element \\
\hline Average Balance & {$[0-1000 €]$} \\
\hline Deposit Portfolio & {$[2.500 €-25.000 €[$} \\
\hline Rate of Effort & $34.60 \%$ \\
\hline Responsibilities in BP & Without other responsibilities \\
\hline LTV & $77.78 \%$ \\
\hline Existence of Guarantors & No \\
\hline
\end{tabular}

Source: Administrative information.

Table 13. Institutional analysis of mortgage loans (partial table)

\begin{tabular}{|c|c|c|c|}
\hline Variables & Categories & Scoring & Decision \\
\hline \multirow{2}{*}{ Profession } & \multirow{2}{*}{ Sector: Primary, Secondary, Tertiary } & $1-5$ & Favourable \\
\hline & & $6-10$ & Unfavourable \\
\hline \multirow{3}{*}{$\begin{array}{l}\text { Employment } \\
\text { Status }\end{array}$} & Effective & $1-2$ & \multirow[b]{2}{*}{ Favourable } \\
\hline & Temporary & $3-4$ & \\
\hline & Unemployed & $6-10$ & Unfavourable \\
\hline \multirow{2}{*}{ Marital Status } & \multirow{2}{*}{ Single, Married, Divorced, Widower } & $1-5$ & Favourable \\
\hline & & $6-10$ & Unfavourable \\
\hline
\end{tabular}


Table 13 continued

\begin{tabular}{|c|c|c|c|}
\hline Variables & Categories & Scoring & Decision \\
\hline \multirow{4}{*}{ Age } & $<24$ Years & 1 & \multirow{3}{*}{ Favourable } \\
\hline & 25-35 Years & 2 & \\
\hline & 36-50 Years & $3-5$ & \\
\hline & $>51$ Years & $6-10$ & Unfavourable \\
\hline \multirow{3}{*}{ Household } & 1 Element & 1 & \multirow{2}{*}{ Favourable } \\
\hline & 2-4 Elements & $2-5$ & \\
\hline & $>5$ Elements & $6-10$ & Unfavourable \\
\hline \multirow{3}{*}{ Cross-selling } & $\begin{array}{l}\text { Customer who holds several financial } \\
\text { products and households his/her salary } \\
\text { in the institution }\end{array}$ & $1-3$ & \multirow[t]{2}{*}{ Favourable } \\
\hline & $\begin{array}{c}\text { Customer who holds a single bank account } \\
\text { and households his/her salary }\end{array}$ & $4-5$ & \\
\hline & $\begin{array}{l}\text { Customer who does not have any } \\
\text { relationship with the institution }\end{array}$ & $6-10$ & Unfavourable \\
\hline \multirow{5}{*}{ Deposit Portfolio } & $>100.000 €$ & 1 & \multirow{4}{*}{ Favourable } \\
\hline & {$[50.000 €-100.000 €]$} & 2 & \\
\hline & {$[25.000 €-50.000 €[$} & 3 & \\
\hline & {$[2.500 €-25.000 €[$} & $4-5$ & \\
\hline & $<2.500 €$ & $6-10$ & Unfavourable \\
\hline \multirow{3}{*}{ Average Balance } & $>1.000 €$ & $1-2$ & \multirow[t]{2}{*}{ Favourable } \\
\hline & {$[0-1000 €]$} & $3-5$ & \\
\hline & $<0 €$ & $6-10$ & Unfavourable \\
\hline \multirow{3}{*}{ Rate of Effort } & $<35 \%$ & $1-2$ & \multirow[t]{2}{*}{ Favourable } \\
\hline & {$[35 \%-45 \%]$} & $3-5$ & \\
\hline & $>45 \%$ & $6-10$ & Unfavourable \\
\hline \multirow{3}{*}{$\begin{array}{l}\text { Responsibilities } \\
\text { in BP }\end{array}$} & Without responsibilities & 1 & \multirow[t]{2}{*}{ Favourable } \\
\hline & With responsibilities but without incident & $2-5$ & \\
\hline & With responsibilities and incident & $6-10$ & Unfavourable \\
\hline \multirow{3}{*}{ LTV } & $<50 \%$ & $1-2$ & \multirow{2}{*}{ Favourable } \\
\hline & {$[50 \%-90 \%]$} & $3-5$ & \\
\hline & $>90 \%$ & $6-10$ & Unfavourable \\
\hline \multirow{2}{*}{$\begin{array}{l}\text { Existence of } \\
\text { Guarantors }\end{array}$} & Yes & $1-5$ & Favourable \\
\hline & No & $6-10$ & Unfavourable \\
\hline
\end{tabular}


End of Table 13

\begin{tabular}{lccc}
\hline \multicolumn{1}{c}{ Variables } & Categories & Scoring & Decision \\
\hline $\begin{array}{l}\text { Economic } \\
\begin{array}{l}\text { Situation of the } \\
\text { Country }\end{array}\end{array}$ & Stable & $1-5$ & Favourable \\
\hline $\begin{array}{l}\text { Political Situation } \\
\text { of the Country }\end{array}$ & Unstable & $6-10$ & Unfavourable \\
\hline
\end{tabular}

Source: Administrative information.

Although not in its entire form, Table 13 allows the identification of partial ratings based on the existence of different categories for all evaluation criteria (i.e. variables). Table 14 allocates information provided in Table 12 to the categories presented in Table 13. This procedure facilitates obtaining partial ratings according to the current system of the bank.

Table 14. Results of the institutional analysis of mortgage loans

\begin{tabular}{|c|c|c|}
\hline Variables & Categories & Scores \\
\hline Profession & Tertiary Sector & 3 \\
\hline Employment Status & Permanent employment (3 Years) & 2 \\
\hline Marital Status & Single & 1 \\
\hline Age & 25-35 Years & 2 \\
\hline Household & 1 Element & 1 \\
\hline Cross-Selling & $\begin{array}{l}\text { Customer who holds a single bank } \\
\text { account and households his/her salary }\end{array}$ & 4 \\
\hline Deposit Portfolio & {$[2.500 €-25.000 €[$} & 4 \\
\hline Average Balance & {$[0-1000 €]$} & 3 \\
\hline Rate of Effort & $<35 \%$ & 2 \\
\hline Responsibilities in BP & Without responsabilities & 1 \\
\hline LTV & {$[50 \%-90 \%]$} & 4 \\
\hline Existence of Guarantors & No & 6 \\
\hline Economic Situation of the Country & Stable with difficulties & 4 \\
\hline Political Situation of the Country & Stable & 3 \\
\hline
\end{tabular}

Source: Administrative information.

The data presented in Table 14 reflect the considerations made in terms of pre-established weights. However, in order to compare the results obtained from the current and "new" models, Table 15 presents a few examples of partial scores calculation, which is anchored in values administratively defined by the bank and considers the trade-offs presented in Table 11. 
Table 15. Score calculation (based on anchored values administratively defined)

\begin{tabular}{lccc}
\hline \multicolumn{1}{c}{ Variables } & $\begin{array}{c}\text { Anchored Values } \\
\text { Administratively } \\
\text { Defined }\end{array}$ & Current Model & "New" Model \\
\hline Profession & $3 \rightarrow 50$ & $50 \cdot 0.12=\mathbf{6}$ & $50 \cdot 0.0882 \cong \mathbf{4}$ \\
\hline Cross-Selling & $4 \rightarrow 40$ & $40 \cdot 0.10=\mathbf{4}$ & $40 \cdot 0.1059 \cong \mathbf{4}$ \\
\hline$[\ldots]$ & {$[\ldots]$} & {$[\ldots]$} & {$[\ldots]$} \\
\hline Rate of Effort & $2 \rightarrow 62.50$ & $62.50 \cdot 0.15=\mathbf{9}$ & $62.50 \cdot 0.1945 \cong \mathbf{1 2}$ \\
\hline LTV & $4 \rightarrow 70$ & $70 \cdot 0.15=\mathbf{1 1}$ & $70 \cdot 0.1195 \cong \mathbf{8}$ \\
\hline
\end{tabular}

$\rightarrow$ Administrative Decision.

Source: Administrative information and data collected through the Delphi application.

As can be observed, partial scores are obtained multiplying the anchored values previously defined by the bank administration by the respective trade-off. As such, a partial score is calculated for each variable, and the sum of all partial scores will correspond to an overall score on which the final decision will rely. Table 16 illustrates the partial and overall scores defined for both evaluation systems (i.e. current and "new").

Table 16. Trade-Offs Readjustment (Current vs. "New")

\begin{tabular}{|c|c|c|c|}
\hline & $\mathrm{N}$ & Current Model & "New" Model \\
\hline Profession & 11 & 6 & 4 \\
\hline Employment Status & 11 & 6 & 9 \\
\hline Marital Status & 11 & 4 & 2 \\
\hline Age & 11 & 3 & 3 \\
\hline Household & 11 & 4 & 1 \\
\hline Cross-Selling & 11 & 4 & 4 \\
\hline Deposit Portfolio & 11 & 1 & 2 \\
\hline Average Balance & 11 & 1 & 3 \\
\hline Rate of Effort & 11 & 9 & 12 \\
\hline Responsibilities in BP & 11 & 15 & 12 \\
\hline LTV & 11 & 11 & 8 \\
\hline Existence of Guarantors & 11 & 1 & 1 \\
\hline Economic Situation of the Country & 11 & 3 & 3 \\
\hline Political Situation of the Country & 11 & 3 & 2 \\
\hline Total & - & 71 & 66 \\
\hline
\end{tabular}

Source: Administrative information and data collected through the Delphi application. 
For our particular application of credit risk evaluation, the current model has an overall score of 71 points, while the "new" modified model has an overall score of 66 points. This means that the "new" model tends to be more "cautious/demanding" (according to the panel members) in terms of the credit approval. Figure 6 allows observing the approval thresholds and associated results obtained.
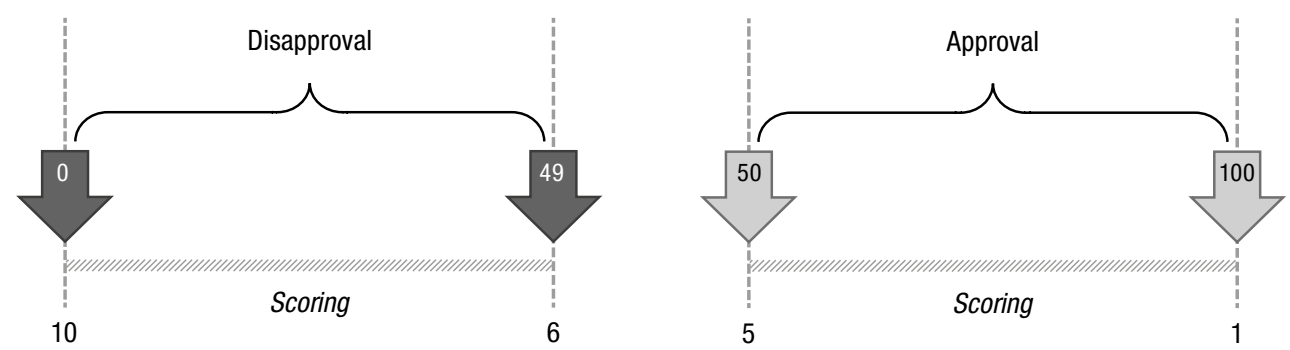

Fig. 6. Overall scores and approval thresholds

Considering that Figure 6 reflects the level of risk of default of a mortgage credit transaction, the credit disapproval should take place when the overall score is between "0" to "49" points (which corresponds to the interval from 6 to 10). For approval, the overall score should be between 50 and 100 points (which corresponds to the interval from 1 to 5). For a complete analysis, one should bear in mind that if the sum of points is set to " 0 ", the level of risk is high, resulting in a final result of "10". As previously discussed, both models indicate a possible approval of the credit application under analysis. However, while the current evaluation model offers a final result closer to " 3 ", the "new" model offers a final result closer to "4", which represents, again, more caution in terms of credit approval (Figure 7).

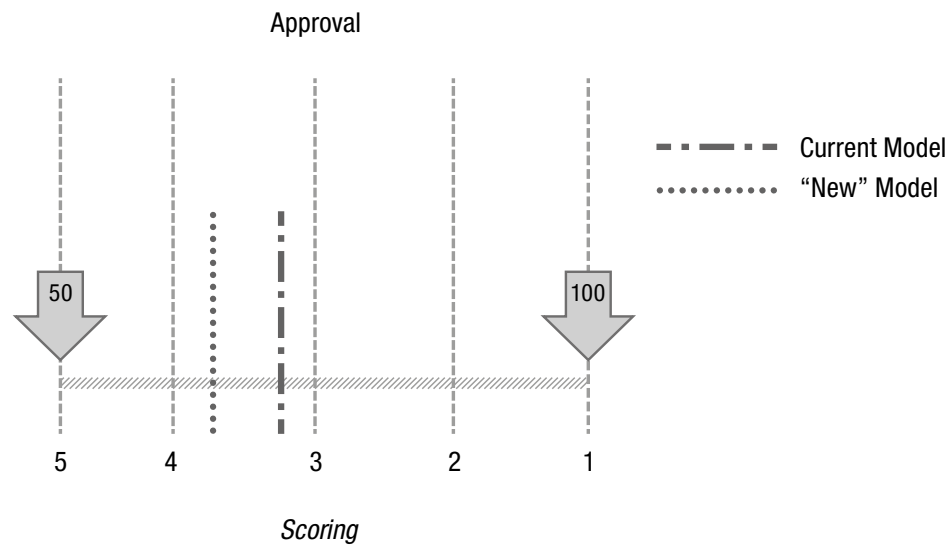

Fig. 7. Overall scores and final results 


\section{Final conclusions and future research}

Mortgage loans are the most highly sought financial product by families in the Portuguese banking system. Because banks have been losing access to money and mediumand long-term debt markets, they have been forced to impose severe restrictions on access to credit, namely in terms of mortgage loans. Therefore, mortgage loans risk evaluation is important and becoming even more important in the future with higher credit underwriting standards. From this viewpoint, remarkable progress has occurred over the past decades in terms of credit risk modeling. However, despite the strengths and widespread application of the current methodologies, models, techniques and/or simple applications, each has specific drawbacks where clarification is required on a number of issues, namely in terms of transparency in the way trade-offs among evaluation criteria are made explicit. Considering this, our use of a Delphi application allows possible readjustment of trade-offs among evaluation criteria, and provides decision makers with a fairer and more transparent mortgage risk evaluation system. Our proposed evaluation system revealed to be more "cautious/demanding" (according to the panel members) in terms of the credit approval, which is in accordance with the Basel directives.

In broader terms, the results achieved by our Delphi application are encouraging. Nevertheless, our framework is not without its limitations. In particular, difficulties in accessing confidential information (e.g. evaluation criteria weights) have been noted. It should also be emphasized that our analysis represents a process-oriented application and, because participants operate in a specific geographical area, results should not be extrapolated. Nonetheless, these limitations were not prohibitive factors in carrying out our analysis and, as a complementary process, we recommend conducting: (1) a different panel study in a different country (e.g. Greece, Ireland, Italy and/or Spain); and (2) a survey to receive feedback from more than just a few panelists. We believe that possible improvements will aid in strengthening the potential and interest of our proposal.

\section{References}

Altman, E.; Saunders, A. 1998. Credit risk measurement: developments over the last 20 years, Journal of Banking \& Finance 21(11/12): 1721-1742.

http://dx.doi.org/10.1016/S0378-4266(97)00036-8

Avery, R.; Calem, P.; Canner, G. 2004. Consumer credit scoring: do situational circumstances matter?, Journal of Banking \& Finance 28(4): 835-856.

http://dx.doi.org/10.1016/j.jbankfin.2003.10.009

Banco de Portugal. 2011a. Cliente Bancário: Crédito à Habitação [online], [cited April 2011]. Available from Internet: http://clientebancario.bportugal.pt/pt-PT/ProdutosBancarios/CreditoaHabitacao/Paginas/default.aspx

Banco de Portugal. 2011b. Cliente Bancário: Responsabilidades de Crédito [online], [cited April 2011]. Available from Internet: http://clientebancario.bportugal.pt/pt-PT/ResponsabilidadesdeCredito/ParticipantesnaCRC/Paginas/default.aspx 
Constantino, R. 2011. O programa de reajustamento: o sector bancário português, InforBanca 89: $13-14$.

Crook, J.; Edelman, D.; Thomas, L. 2007. Recent developments in consumer credit risk assessment, European Journal of Operational Research 183(3): 1447-1465.

http://dx.doi.org/10.1016/j.ejor.2006.09.100

Dalkey, N. 1969. The Delphi Method: An Experimental Study of Group Opinion. United States Air Force Project Rand: Rand Santa Monica Company [online], [cited June 2011]. Available from Internet: http://www.rand.org/content/dam/rand/pubs/research_memoranda/2005/RM5888.pdf.

Dalkey, N.; Helmer, O. 1963. An experimental application of the Delphi method to the use of experts, Management Science 9(3): 458-467 [cited June 2011]. Available from Internet: http:// www.jstor.org/pss/2627117

Doumpos, M.; Kosmidou, K.; Baourakis, G.; Zopounidis, C. 2002. Credit risk assessment using a multicriteria hierarchical discrimination approach: a comparative analysis, European Journal of Operational Research 138(2): 392-412. http://dx.doi.org/10.1016/S0377-2217(01)00254-5

Doumpos, M.; Zopounidis, C. 2001. Assessing financial risks using a multicriteria sorting procedure: the case of country risk assessment, Omega 29(1): 97-109.

http://dx.doi.org/10.1016/S0305-0483(00)00028-1

Fernandes, G. 2010. Aplicação da metodologia Delphi na definição de estratégias de gestão territorial, in Proceedings of the 16th APDR Congress. University of Madeira, 1826-1849.

Ferreira, F. 2003. Inovação Tecnológica no Sistema Financeiro Português: Evolução e Perspectivas. $1^{\text {st }}$ ed. Coimbra: Pé de Página Editores.

Ferreira, F.; Monteiro Barata, J. 2011. A snapshot of the Portuguese e-banking activity: insights and a conceptual framework to allocate strategic hindrances, International Journal of Electronic Business 9(3): 238-254. http://dx.doi.org/10.1504/IJEB.2011.042544

Ferreira, F.; Santos, S.; Rodrigues, P. 2011. Adding value to bank branch performance evaluation using cognitive maps and MCDA: a case study, Journal of the Operational Research Society 62(7): 1320-1333. http://dx.doi.org/10.1057/jors.2010.111

Grunert, J.; Norden, L.; Weber, M. 2005. The role of non-financial factors in internal credit ratings, Journal of Banking \& Finance 29(2): 509-531. http://dx.doi.org/10.1016/j.jbankfin.2004.05.017

Hsu, C.; Sandford, B. 2007. The Delphi technique: making sense of consensus, Practical Assessment, Research and Evaluation 12(10): 1-18 [online], [cited June 2011]. Available from Internet: http://pareonline.net/pdf/v12n10.pdf

Ince, H.; Aktan, B. 2009. A comparison of data mining techniques for credit scoring in banking: a managerial perspective, Journal of Business Economics and Management 10(3): 233-240.

http://dx.doi.org/10.3846/1611-1699.2009.10.233-240

JRC - Joint Research Centre/European Commission. 2011. Delphi Survey [online], [cited July 2011]. Available from Internet: http://forlearn.jrc.ec.europa.eu/guide/2_scoping/meth_Delphi.htm Lima, S.; Vaz, M.; Baptista, M.; Ramos, A.; Leitão, M.; Cunha, M. 1995. Operações Bancárias II $6^{\text {th }}$ ed. IFB - Instituto Formação Bancária, Lisbon.

Lopez, J.; Saidenberg, M. 2000. Evaluating credit risk models, Journal of Banking \& Finance 24(1): 151-165. http://dx.doi.org/10.1016/S0378-4266(99)00055-2

Mačerinskienė, I.; Ivaškevičiūtè, L. 2008. The evaluation model of a commercial bank loan portfolio, Journal of Business Economics and Management 9(4): 269-277.

http://dx.doi.org/10.3846/1611-1699.2008.9.269-277

Mari, C.; Renò, R. 2005. Credit risk analysis of mortgage loans: an application to the Italian market, European Journal of Operational Research 163(1): 83-93.

http://dx.doi.org/10.1016/j.ejor.2003.12.007 
Šečkute, L.; Pabedinskaite, A. 2003. Application of forecasting methods in business, Journal of Business Economics and Management 4(2): 144-157.

http://dx.doi.org/10.1080/16111699.2003.9636048

Suhobokov, A. 2007. Application of Monte Carlo simulation methods in risk management, Journal of Business Economics and Management 8(3): 165-168.

http://dx.doi.org/10.1080/16111699.2007.9636165

Thomas, L. 2009. Modelling the credit risk for portfolios of consumer loans: analogies with corporate loan models, Mathematics and Computers in Simulation 79(8): 2525-2534.

http://dx.doi.org/10.1016/j.matcom.2008.12.006

Twala, B. 2010. Multiple classifier application to credit risk assessment, Expert Systems with Applications 37(4): 3326-3336. http://dx.doi.org/10.1016/j.eswa.2009.10.018

Wang, G.; Hao, J.; Mab, J.; Jiang, H. 2011. A comparative assessment of ensemble learning for credit scoring, Expert Systems with Applications 8(1): 223-230.

http://dx.doi.org/10.1016/j.eswa.2010.06.048

Yu, L.; Wang, S.; Lai, K. 2009. An intelligent-agent-based fuzzy group decision making model for financial multicriteria decision support: the case of credit scoring, European Journal of Operational Research 195(3): 942-959. http://dx.doi.org/10.1016/j.ejor.2007.11.025 


\section{APPENDIXES}

Appendix 1: Delphi Survey - Round 1

Escola Superior

de Gestão e

Tecnologia

[ipSantarém]

\section{DELPHI SURVEY (ROUND 1)}

Contact: 070117037@esg.ipsantarem.pt

Obs.: The present survey is composed of a single table and respective items. To ensure the anonymity of institutions and individuals involved, all statements provided, and their statistical treatment, will be fully confidential.

In terms of mortgage loan risk evaluation, what is the degree of importance (i.e. weight) that you give to each one of the following criteria? [From 1 to $100(1=$ Very minor importance, $50=$ Moderate importance and $100=$ Extreme importance), mark your preference for each criterion. Please, note that the sum of the weights should be $100 \%$ ].

\begin{tabular}{|c|c|c|}
\hline Area & Criteria & Degree of Importance \% \\
\hline \multirow{5}{*}{$\begin{array}{l}\text { Analysis of Customer } \\
\text { Characteristics }\end{array}$} & - Profession & \\
\hline & - Employment Status & \\
\hline & - Marital Status & \\
\hline & - Age & \\
\hline & - Household & \\
\hline \multirow[t]{3}{*}{ Analysis of Customer Behavior } & - Cross-selling & \\
\hline & - Deposit Portfolio & \\
\hline & - Average Balance & \\
\hline \multirow[t]{4}{*}{ Analysis of Customer Documents } & - Rate of Effort & \\
\hline & - Responsibilities in BP & \\
\hline & $-\mathrm{LTV}$ & \\
\hline & - Existence of Guarantors & \\
\hline \multirow[t]{3}{*}{ Analysis of the Environment } & - Economic Situation & \\
\hline & - Political Situation & \\
\hline & Total: & $100 \%$ \\
\hline
\end{tabular}

\section{End of Survey}

Thank You for Your Cooperation! 


\section{Appendix 2: Delphi Survey - Round 2}

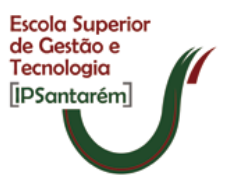

\section{DELPHI SURVEY (ROUND 2)}

Contact: 070117037@esg.ipsantarem.pt

In terms of mortgage loan risk evaluation, what is the degree of importance (i.e. weight) that you give to each one of the following criteria? [From 1 to $100(1=$ Very minor importance, $50=$ Moderate importance and $100=$ Extreme importance), mark your preference for each criterion. Please, note that the sum of the weights should be $100 \%$ ].

\begin{tabular}{|c|c|c|c|c|c|}
\hline \multirow{3}{*}{ Area } & \multirow{3}{*}{ Criteria } & \multicolumn{4}{|c|}{ Degree of Importance \% } \\
\hline & & \multicolumn{3}{|c|}{ Round 1} & \multirow[b]{2}{*}{ Round 2} \\
\hline & & Mean & Median & $\begin{array}{l}\text { Standard } \\
\text { Deviation }\end{array}$ & \\
\hline \multirow{5}{*}{$\begin{array}{l}\text { Analysis } \\
\text { of Customer } \\
\text { Characteristics }\end{array}$} & - Profession & 8.31 & 6.5 & 5.97 & \\
\hline & - Employment Status & 10.69 & 10 & 5.45 & \\
\hline & - Marital Status & 2.62 & 2 & 1.98 & \\
\hline & - Age & 3.54 & 3 & 2.57 & \\
\hline & - Household & 2.27 & 2 & 1.88 & \\
\hline \multirow{3}{*}{$\begin{array}{l}\text { Analysis } \\
\text { of Customer } \\
\text { Behavior }\end{array}$} & - Cross-selling & 11.27 & 10 & 4.27 & \\
\hline & - Deposit Portfolio & 5.92 & 5 & 1.93 & \\
\hline & - Average Balance & 6.46 & 6 & 2.5 & \\
\hline \multirow{4}{*}{$\begin{array}{l}\text { Analysis of } \\
\text { Customer } \\
\text { Documents }\end{array}$} & - Rate of Effort & 15.65 & 12.5 & 7.59 & \\
\hline & - Responsibilities in BP & 9.31 & 10 & 4.07 & \\
\hline & $-\mathrm{LTV}$ & 13.81 & 10 & 3.79 & \\
\hline & - Existence of Guarantors & 3.77 & 5 & 2.83 & \\
\hline \multirow{3}{*}{$\begin{array}{l}\text { Analysis of the } \\
\text { Environment }\end{array}$} & - Economic Situation & 3.81 & 3 & 2.69 & \\
\hline & - Political Situation & 2.57 & 2 & 2.25 & \\
\hline & Total: & - & - & - & $100 \%$ \\
\hline
\end{tabular}

End of Survey

Thank You for Your Cooperation! 
Fernando A. F. FERREIRA is an Adjunct Professor and Vice President of the Scientific Council at the School of Management and Technology of the Polytechnic Institute of Santarém, Portugal, and Adjunct Research Professor at the University of Memphis, TN, USA. He holds a PhD in Quantitative Methods Applied to Economics and Management from the University of Algarve, Portugal. In 2009, he was granted with a Calouste Gulbenkian Foundation fellowship for Post-Doctoral studies at the Fogelman College of Business and Economics of the University of Memphis. He has authored books, book chapters, peer-reviewed papers and made many conference presentations. His research interests include multiple criteria decision analysis and integrated systems for performance measurement in the banking sector.

Ronald W. SPAHR is a Professor and Former Chairman in the Department of Finance, Insurance and Real Estate of the Fogelman College of Business and Economics of the University of Memphis, TN, USA. He received his PhD and MBA from the University of Wisconsin-Madison, MS in Operations Management from the University of Southern California and BS in Mechanical Engineering from South Dakota State University. Previously, he was the National City Bank Distinguished Professor of Banking and Finance at the University of Illinois, Belk Distinguished Professor of Finance at the University of North Carolina and Professor of Finance at the University of Wyoming. He has also lectured at a number of European universities.

Irina F. M. D. GAVANCHA is a bank analyst who works at Caixa Geral de Depósitos (one of the top-five banks in Portugal). Her major research interests include credit risk analysis in mortgage loans.

Amali ÇIPI is a Lecturer at the University of Vlora "Ismail Qemali”, Albania. She received her MBA from the University of Tirana, Albania and University of Nebraska, NE, USA. Currently, she is a PhD student at the University of Tirana. Her main research interests include corporate governance practices and applications of the Delphi technique. She has authored peer-reviewed papers and some of her works have been presented in international conferences. 